\title{
PENGEMBANGAN INTERACTIVE PROBLEM BASED MODULE UNTUK MENINGKATKAN KETERAMPILAN BERPIKIR KRITIS DAN PENGUASAAN KONSEP IPA
}

\author{
B. Seftian ${ }^{1)}$, Anna Permanasari ${ }^{2)}$, Bibin Rubini ${ }^{3)}$ \\ ${ }^{1)}$ Program Studi Pendidikan IPA, Universitas Pakuan \\ 2) Dosen Program Studi Pendidikan IPA, Universitas Pendidikan Indonesia \\ ${ }^{3)}$ Dosen Program Studi Pendidikan IPA, Universitas Pakuan
}

Email:

\begin{abstract}
Abstrak: Penelitian ini dilakukan dengan menggunakan metode Research and Development (R\&D) terbatas dengan desain ADDIE yang diharapkan akan menghasilkan produk berupa Interactive Problem Based Module (IPBM). Penelitian selanjutnya dilakukan untuk mengetahui efektifitas dari IPBM terhadap peningkatan keterampilan berpikir kritis (CT) dan penguasaan konsep IPA siswa pada materi kepadatan populasi dan pencemaran lingkungan. Penelitian ini dilaksanakan pada salah satu SMP di Kota Bogor semester genap tahun 2017. Populasi penelitian berjumlah 33 orang siswa yang ditentukan secara purposive sampling. Penelitian pre-eksperimen ini dilakukan dengan pre-post test design. Instrumen tes yang digunakan berupa soal pilihan ganda dan uraian yang sebelumnya telah diuji terhadap item tes berupa uji validitas, uji reliabilitas, tingkat kesukaran butir soal, dan daya pembeda soal. IPBM divalidasi oleh ahli dari segi media maupun materi dengan penilaian dalam kategori sangat baik. Hasil penelitian menunjukkan bahwa penggunaan IPBM dalam pembelajaran dapat meningkatkan keterampilan berpikir kritis dan penguasaan konsep IPA dengan baik. Hal tersebut dapat dilihat dari data yang diperoleh Hasil implementasi terlebih menyeluruh terhadap penggunaan IPBM dalam pembelajaran dapat meningkatkan Keterampilan Berpikir Kritis siswa dengan \% $\mathrm{N}$-gain 48, dan meningkatkan Penguasaan Konsep siswa dengan \%N-gain 40. Siswa yang memenuhi kriteria ketuntasan adalah 27 orang dari 33 siswa.
\end{abstract}

Kata Kunci: Interactive Problem Based Module, Keterampilan Berpikir Kritis, Penguasaan Konsep

\section{PENDAHULUAN}

Perkembangan ilmu pengetahuan dan teknologi yang pesat saat ini, menuntut setiap individu memiliki kemampuan yang berkualitas agar mampu bersaing. Individu yang memiliki kualitas yang baik diperoleh melalui pendidikan yang baik. Pendidikan merupakan salah satu ujung tombak yang menopang maju dan berkembangnya suatu bangsa. Kemajuan suatu bangsa dapat terlihat dari 
kualitas masyarakatnya terutama dalam bidang pendidikan. Akan tetapi, proses dalam mencapai pendidikan yang bermutu dan berkualitas dalam suatu sistem pendidikan masih menemui berbagai kendala terutama berbagai kendala yang terjadi di lapangan atau di kelas ketika proses pembelajaran.

Kegiatan pembelajaran yang dilakukan guru memiliki peran penting demi tercapainya tujuan pembelajaran yang tentunya akan menunjang siswa memperoleh hasil belajar yang baik. Menurut Bloom dalam Suprijono (2010), hasil belajar siswa terdiri dari tiga aspek yaitu pengetahuan (kognitif), sikap (afektif) dan keterampilan (psikomotor) secara hierarki. Agar memperoleh hasil belajar yang baik maka seorang guru haruslah inovatif dalam mengelola pembelajaran di kelas salah satu caranya dengan menggunakan model dan metode yang menarik sehingga dapat meningkatkan minat dan motivasi siswa dalam belajar dan menciptakan situasi yang mendukung untuk belajar sehingga akan berdampak langsung pada hasil belajar siswa.

Berdasarkan hasil observasi di lapangan tempat akan dilakukannya penelitian pada kelas VII disalah satu SMP Kota Bogor diketahui terdapat berbagai permasalahan yang terjadi dalam pembelajaran yaitu kurangnya motivasi siswa dalam belajar yang berdampak pada kurang maksimalnya pencapaian KKM siswa yang kurang maksimal pada tahun ajaran 2015-2016. Hal ini dapat dilihat dari prosentase pencapaian KKM siswa yang mencapai 65\% atau sekitar 26 siswa dari jumlah total 40 siswa. Sedangkan siswa yang belum mencapai KKM sekitar $35 \%$ atau 14 siswa. KKM yang ditentukan dalam mata pelajaran IPA kelas VII yaitu 72 .

Selain hasil belajar dari aspek kognitif (pengetahuan) yang belum maksimal adapun dari aspek keterampilan, khususnya keterampilan berpikir kritis (critical thinking) siswa kurang berkembang. Seharusnya pada masa ini siswa sudah mampu belajar menyelesaikan suatu permasalahan dan memberikan solusi baik secara lisan maupun tulisan yang dapat diaplikasikan dalam kehidupan sehari-hari sesuai dengan materi yang dipelajari di sekolah. Oleh karena itu, perlu kiranya guru melakukan inovasi dalam bentuk pengembangan bahan ajar atau media pembelajaran yang menarik sehingga mampu meningkatkan motivasi belajar dan merangsang siswa untuk meningkatkan keterampilan berpikir kritisnya. Media pembelajaran yang dapat digunakan salah satunya yaitu media berbasis visual. Levie \& Lentz (1982) dalam Arsyad (2013) mengemukakan empat fungsi media pembelajaran khususnya visual, yaitu fungsi atensi, fungsi afektif, fungsi kognitif, dan fungsi kompensatoris. Modul merupakan salah satu media visual yang dapat berfungsi sebagai bahan ajar yang di dalamnya memiliki fungsi afektif, yaitu dengan membaca teks yang disertai gambar dapat mengunggah emosi dan sikap siswa, misalnya informasi yang menyangkut masalah sosial atau ras. 
Berdasarkan uraian pada latar belakang, beberapa masalah terkait pembelajaran IPA teridentifikasi sebagai berikut: 1) Rendahnya penguasaan konsep IPA siswa, 2) Rendahnya keterampilan berpikir kritis siswa, 3) Terbatasnya media atau bahan ajar yang mampu mendukung pencapaian hasil belajar dan keterampilan berpikir kritis siswa. Ketiga permasalahan tersebut telah dicoba ditemukan solusinya melalui penelitian ini. Adapun rumusan masalah yang diangkat adalah “Apakah Penggunaan Interactive Problem Based Module (IPBM) dapat Meningkatkan Keterampilan Berpikir Kritis dan Penguasaan Konsep IPA Siswa?. Berbagai masalah yang telah teridentifikasi di atas dirumuskan dalam beberapa pertanyaaan yang dirumuskan dalam penelitian ini sebagai berikut:

1) Bagaimanakah karakteristik modul yang mencerminkan keterampilan berpikir kritis siswa?

2) Bagaimanakah peningkatan keterampilan berpikir kritis siswa setelah pembelajaran dengan Interactive Problem Based Module (IPBM)?

3) Bagaimanakah penguasaan konsep IPA siswa setelah pembelajaran dengan Interactive Problem Based Module (IPBM)?

\section{METODE PENELITIAN}

Penelitian ini akan dilakukan dengan menggunakan metode Research and Development (R\&D) yang diharapkan akan menghasilkan produk berupa Interactive Problem Based Module (IPBM). Mengingat keterbatasan waktu, maka penelitian R\&D dibatasi hanya sampai pada langkah ujicoba terbatas saja yang dilakukan di dalam satu kelas eksperimen. Untuk menguji efektifitas dalam meningkatkan penguasaan konsep dan keterampilan berpikir kritis siswa, maka akan dilakukan studi lebih lanjut menggunakan metode kuasi eksperimen dengan pre-post test design.

Populasi yang digunakan dalam penelitian ini adalah seluruh siswa kelas VII disalah satu SMP Kota Bogor tahun ajaran 2016-2017. Penentuan sampel dilakukan menggunakan teknik purposive sampling, yaitu teknik pengambilan sampel dengan pertimbangan tertentu yang didasarkan pada kriteria yang akan diterapkan berdasarkan tujuan penelitian. Berdasarkan teknik purposive sampling, sampel yang dipilih untuk yang diteliti yaitu 33 orang siswa kelas VII dari empat kelas yaitu kelass VII-A sebagai kelas perlakuan dengan menggunakan media pembelajaran Interactive Problem Based Module (IPBM).

Metode penelitian dan pengembangan (Research and Development) dengan desain ADDIE (Analysis, Design, Development, Implementation, Evaluation). Tahapan metode penilitian pengembangan dengan desain ADDIE yang dilakukan pada penelitian ini mengikuti tahapan metode penelitian pengembangan desain ADDIE yang dikemukakan (Dick dan Carey, 1996) seperti terlihat pada Gambar 1.1 


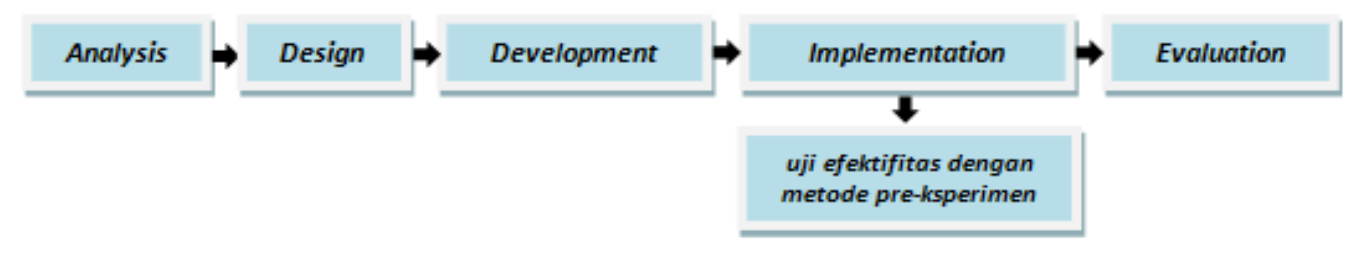

Gambar 1.1. Tahapan Metode Penelitian dan Pengembangan yang dimodifikasi

Gambar 1.1 menunjukkan tahapan pelaksanaan metode penelitian dan pengembangan dengan desain ADDIE. Adapun penjabarannya sebagai berikut :

\section{Analisis (Analysis)}

Analisis yang dilakukan dalam penelitian ini berdasarkan dari potensi dan masalah yang ditemukan dari hasil pengumpulan data melalui studi pendahuluan baik dengan kajian literatur maupun studi lapangan. Studi lapangan dilakukan dengan observasi kelas di sekolah yang akan menjadi objek penelitian. Studi pendahuluan ini bertujuan untuk mendapatkan data dan informasi yang diperlukan pada penelitian. Adapun rincian yang dilakukan pada studi pendahuluan untuk mengumpulkan informasi dan data adalah sebagai berikut :

a) Melakukan analisis standar isi pada kompetensi dasar mata pelajaran IPA SMP Kelas VII untuk mendapatkan gambaran kompetensi dasar dan indikator yang harus dicapai pada pembelajaran IPA.

b) Melakukan analisis materi pelajaran IPA SMP Kelas VII pada materi kepadatan populasi dan pencemaran lingkungan yang terdapat dalam buku yang digunakan pada pembelajaran di kelas.

c) Melakukan studi kepustakaan mengenai keterampilan berpikir kritis dan penguasaan konsep. Studi kepustakaan mengenai keterampilan berpikir kritis dan penguasaan konsep bertujuan untuk mendapatkan gambaran tentang keterampilan berpikir kritis dan penguasaan konsep dalam perkembangannya dalam pembelajaran kelas. Studi kepustakaan ini menggunakan artikel dan jurnal pendidikan.

d) Melakukan analisis indikator keterampilan berpikir kritis yang dikembangkan Ennis (1985)

e) Melakukan observasi dan wawancara untuk mengetahui proses pembelajaran IPA berkaitan dengan kurikulum pembelajaran IPA dan bahan ajar serta kaitannya dengan peningkatan keterampilan berpikir kritis dan penguasaan konsep siswa. Observasi langsung dilakukan pada sekolah yang akan dituju sebagai objek penelitian yaitu salah satu SMP di kota Bogor dan sekitarnya. 


\section{Desain (Design)}

Langkah awal yang dilakukan yaitu merancang produk yang akan di kembangkan. Produk yang dikembangkan berupa Interactive Problem Based Module (IPBM). Tahapan yang dilakukan dalam proses mendesain yaitu:

a) Merumuskan indikator dan tujuan pembelajaran aspek kognitif melalui telaah konten materi pelajaran IPA yang jadikan acuan untuk mengembangkan IPBM yang akan berpengaruh pada meningkatnya keterampilan berpikir kritis dan penguasaan konsep IPA.

b) Melakukan penyusunan kisi-kisi alat ukur keterampilan berpikir kritis dan penguasaan konsep IPA pada materi kepadatan populasi dan pencemaran lingkungan yang disesuaikan dengan indikator dan konten materi dalam buku atau bahan ajar yang akan di kemas dalam modul berbasis masalah.

c) Membuat rancangan IPBM

\section{Pengembangan (Development)}

Tahap pengembangan merupakan tahap dimana modul yang telah di desain akan divalidasi oleh ahli dan guru. Setelah modul tersebut divalidasi maka akan diujicobakan secara terbatas yang hasilnya akan menjadi bahan untuk mengevalusi modul tersebut sebelum diimplementasikan dalam kegiatan pembelajaran.

\section{Implementasi (implementation)}

Tahap implementasi dilakukan untuk menguji efektifitas pembelajaran menggunakan buku ajar berbasis masalah pada pembelajaran IPA. Pada tahap implementasi ini dirancang penelitian dengan metode pra eksperimen dengan desain pretest-posttest design (Frankel, et al, 2011). Desain ini digunakan untuk melihat perbedaan hasil belajar sebelum dan sesudah perlakuan. Desain ini hanya menggunakan satu kelas sebagai kelas yang diberikan perlakuan pembelajaran dengan menggunakan IPBM (Interactive Problem based Module). Metode preeksperimen dengan desain pretest-posttest design dapat dilihat pada Tabel 1.1.

Tabel 1.1 Pretest-Postest Design

\begin{tabular}{|c|c|c|}
\hline $\mathrm{O}_{1}$ & $\mathrm{X}$ & $\mathrm{O}_{2}$ \\
\hline Pretest & Perlakuan menggunakan & Posttest \\
& Interactive Problem Based Module & \\
\hline
\end{tabular}

Pada Tabel 1.1 akan diketahui efektifitas pembelajaran menggunakan IPBM pada materi kepadatan populasi dan pencemaran lingkungan. Hal tersebut dapat dilihat dari nilai pretest dan posttest yang diperoleh siswa. Sementara itu efektifitas pembelajaran menggunakan IPBM terhadap peningkatan keterampilan berpikir kritis dan penguasaan konsep dapat di lihat dari meningkatnya nilai siswa. 


\section{Evaluasi (Evaluation)}

Tahap evaluasi merupakan tahap akhir pada pelaksanaan penelitian dan pengembangan dengan desain ADDIE. Pada tahap ini dilakukan pemberian angket kepada siswa untuk mengetahui tanggapan siswa mengenai penggunaan modul berbasis masalah pada pembelajaran IPA.

Hasil tanggapan siswa dijadikan sebagai data tambahan untuk menjawab rumusan masalah dan pertannyaan penelitian yang diajukan. Selain itu, hasil angket juga dijadikan sebagai masukan untuk perbaikan modul yang sudah dikembangkan.

\section{HASIL DAN PEMBAHASAN}

\section{a. Karakteristik Modul}

Interactive Problem Based Module (IPBM) adalah modul yang disusun sebagai bahan ajar yang berfungsi untuk mengembangkan atau meningkatkan kemampuan berpikir kritis dan penguasaan konsep siswa dalam materi pembelajaran. IPBM yang disusun mencakup materi Kepadatan Populasi dan Pencemaran Lingkungan dimana berbagai permasalahannya terdapat dalam kehidupan sehari-hari sehingga mampu menstimulus siswa dalam berpikir dan memberikan solusi pada permasalahan yang ada. IPBM memiliki beberapa karakteristik diantaranya; aspek pedagogi, aspek konten, aspek teknis dan aspek estetika yang terlah disesuaikan dengan karakter siswa. Dilihat dari segi teknis IPBM bersifat self instructional, adaptive, dan user friendly.

IPBM yang dirancang terlebih dahulu diuji kelayakannya. Uji kelayakan dilakukan oleh ahli yaitu 2 dosen dan 4 guru bidang studi IPA. Validasi media dilakukan oleh dosen ahli yang bertujuan untuk mengetahui kelayakkan dan kesesuaian modul terhadap materi pembelajaran yang akan di sampaikan. Data validasi yang didapat digunakan sebagai tolak ukur kelayakkan modul baik dari segi kemudahan penggunaan maupun keterkaitan materi. Selain itu saran dan pendapat yang diberikan diharapkan mampu menjadi bahan untuk merevisi modul agar sesuai dengan ketentuan dan karakteristik yang diinginkan. Berdasarkan data validasi media, validator memberikan skor sebesar 74 dari 19 pernyataan dengan skor maksimum 76. Dari skor tersebut diperoleh persentase sebesar 97,37\% sehingga media yang divalidasi termasuk dalam kategori sangat baik. Sedangkan Validasi materi dilakukan oleh dosen ahli yang bertujuan untuk mengetahui kesesuaian standar kompetensi dan kompetensi dasar dengan materi yang ada dalam modul pembelajaran. Berdasarkan data validasi materi, validator memberikan skor sebesar 83 dari 22 pernyataan dengan skor maksimum 88 . Dari skor tersebut diperoleh persentase sebesar $94,32 \%$ sehingga materi yang divalidasi termasuk dalam kategori sangat baik. 
Validasi yang dilakukan oleh guru bertujuan untuk mengetahui kesesuaian standar kompetensi dan kompetensi dasar dengan materi yang ada dalam modul pembelajaran. Berdasarkan data penilaian guru IPA SMP terhadap media, diperoleh data bahwa guru IPA SMP memberikan penilaian dalam kategori sangat baik. Hal tersebut dapat dilihat dari rata-rata persentase dari empat aspek yaitu sebesar 87,11\% dengan rincian sebagai berikut: Aspek pedagogik 84,38\%, Aspek konten 89,06\%, Aspek teknis 89,58\%, dan Aspek estetika 85,42\%. Oleh karena itu, dari rincian data hasil validasi IPBM yang dilakukan oleh validator media dengan persentase $97,37 \%$, validator materi dengan persentase $94,32 \%$ dan guru bidang studi IPA dengan persentase $87,11 \%$. Hal ini menunjukkan bahwa IPBM memiliki penilaian dalam kategori sangat baik.

Pengujian efektifitas modul pembelajaran berbasis masalah dilakukan di salah satu SMP Swasta di Bogor pada semester genap tahun ajaran 2016-2017 pada materi Kepadatan Populasi dan Pencemaran Lingkungan. Target untuk menguji efektifitas modul yaitu kelas VII-A dengan jumlah siswa 33 orang. Data yang digunakan untuk mengetahui efektifitas modul diperoleh dari kegiatan pretest dan posttest yang diberikan kepada siswa yaitu dengan memberikan 2 jenis tipe soal, Pilihan ganda (PG) untuk mengetahui penguasaan konsep siswa dan uraian untuk mengetahui keterampilan berpikir kritis (KBK) siswa.

\section{b. Penguasaan Konsep}

Efektifitas penggunaan modul pembelajaran terhadap peningkatan penguasaan konsep diteliti berdasarkan pada analisis hasil pretest dan posttest. Soal berupa pilihan ganda berjumlah 20 butir soal dengan ranah kognitif yang digunakan yaitu pengetahuan $\left(\mathrm{C}_{1}\right)$, pemahaman $\left(\mathrm{C}_{2}\right)$, penerapan $\left(\mathrm{C}_{3}\right)$, dan aplikasi $\left(\mathrm{C}_{4}\right)$. Hasil analisis pretest dan posttest pada penguasaan konsep siswa ditunjukkan pada Tabel 1.2.

Tabel 1.2 Hasil Analisis Pretest dan Postest Penguasaan Konsep Siswa

\begin{tabular}{|c|c|c|c|}
\hline No. & Data Implementasi & Pretest & Posttest \\
\hline 1 & Jumlah Siswa & 33 orang & 33 orang \\
\hline 2 & Rata-rata Penguasaan Konsep & 69,8 & 82,1 \\
\hline 3 & Nilai Tertinggi & 85 & 95 \\
\hline 4 & Nilai Terendah & 50 & 70 \\
\hline 5 & \%N-Gain & \multicolumn{2}{|c|}{40} \\
\hline 6 & N-gain & \multicolumn{2}{|c|}{ (sedang) } \\
\hline
\end{tabular}

Berdasarkan pengamatan terhadap hasil uji coba, ditemukan beberapa hal yang sangat menarik untuk dikaji yaitu terdapat temuan bahwa siswa masih kesulitan menyelesaikan soal-soal terutama pada domain soal $\mathrm{C}_{2}$ dan $\mathrm{C}_{4}$. Oleh karena itu dapat disimpulkan bahwa siswa memiliki \% N-Gain yang rendah pada tipe soal $\mathrm{C}_{2}$ dan $\mathrm{C}_{4}$ yang mungkin disebabkan karena banyaknya jumlah soal tipe 
$\mathrm{C}_{2}$ dan tingkat kesulitan dari soal tipe $\mathrm{C}_{4}$. Walaupun demikian dari data tersebut diperolah rerata $\% \mathrm{~N}-$ Gain $33 \%$ yang termasuk dalam kriteria sedang.

Berdasarkan data analisa penguasaan konsep siswa dengan melakukan pengujian soal pretest dan posttest yang terdiri dari soal $\mathrm{C}_{1}, \mathrm{C}_{2}, \mathrm{C}_{3}$ dan $\mathrm{C}_{4}$ dapat diketahui bahwa penguasaan konsep siswa dalam kategori sedang pada tipe soal $\mathrm{C}_{1}$ dan $\mathrm{C}_{3}$, sedangkan untuk tipe soal $\mathrm{C}_{2}$ dan $\mathrm{C}_{4}$ penguasaan konsep siswa dalam kategori rendah. Untuk mengetahui lebih jelas dalam membandingkan nilai ratarata pretest, posttest, dan $\mathrm{N}$-gain pada penguasaan konsep dapat dilihat pada Gambar 1.2.

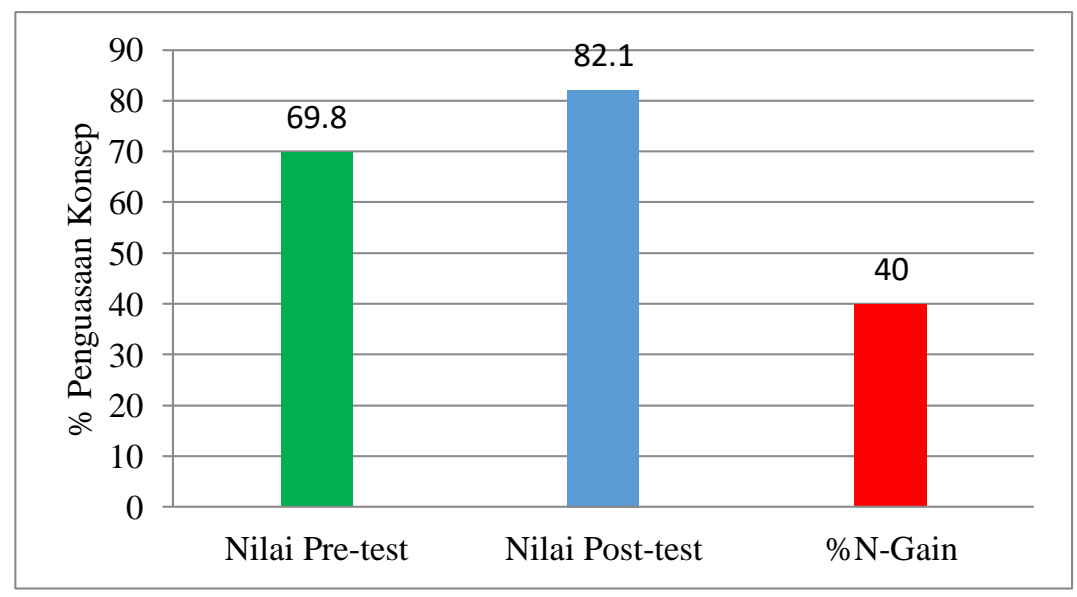

Gambar 1.2 Peningkatan Penguasaan Konsep Siswa

Berdasarkan data hasil analisis soal pilihan ganda pretest dan posttest dari 33 siswa terdapat 6 siswa memiliki peningkatan penguasaan konsep dalam kategori tinggi dengan nilai $\% \mathrm{~N}$-gain > 70, 13 siswa memiliki peningkatan penguasaan konsep dalam kategori sedang dengan nilai $\% \mathrm{~N}$-gain diantara 30-70, 11 siswa memiliki peningkatan penguasaan konsep dalam kategori rendah dengan nilai $\% \mathrm{~N}$-gain $<30$, sedangkan 3 siswa yang penguasaan konsepnya tidak berubah yaitu $\% \mathrm{~N}$-gain 0 .

Nilai rata-rata yang diperoleh siswa untuk pretest 70 , posttest 82 , dan $\% \mathrm{~N}$ gain 40. Nilai $\mathrm{N}$-gain menunjukkan efektifitas pembelajaran dengan kategori sedang. Hasil tersebut menunjukkan bahwa terdapat peningkatan penguasaan konsep dengan menggunakan IPBM dalam pembelajaran dari pretest ke posttest. Peningkatan yang terjadi disebabkan oleh proses pembelajaran yang melibatkan siswa secara aktif dalam menyelesaikan masalah dalam kehidupan sehari-hari yang dikemas secara menarik dalam modul. Hal ini sejalan dengan yang dikemukakan College of Education, University of Washington (2001) dalam (Syafii \& Yasin, 2013), yang menyatakan bahwa penggunaan masalah kehidupan nyata sebagai konteks pemikiran siswa dapat membantu mereka tidak hanya memecahkan masalah, tetapi juga memahami pengetahuan penting dan konsep. 


\section{c. Keterampilan Berpikir Kritis}

Keterampilan berpikir kritis siswa dalam peneitian ini diases dengan menggunakan soal uraian. Hasil analisis keterampilan berpikir kritis siswa sebelem dan sesudah perlakuan dapat dilihat pada Tabel 1.4.

Tabel 1.4 Hasil Analisis Pretest dan Postest Keterampilan Berpikir Kritis Siswa

\begin{tabular}{cccc}
\hline No. & Data Implementasi & Pretest & Posttest \\
\hline 1 & Jumlah Siswa & 33 orang & 33 orang \\
\hline 2 & Rata-rata Penguasaan Konsep & 41,89 & 70,9 \\
\hline 3 & Nilai Tertinggi & 77,5 & 92,5 \\
\hline 4 & Nilai Terendah & 17,5 & 45 \\
\hline 5 & \%N-Gain & & \\
\hline 6 & N-gain & 0,48 & \\
\hline \multicolumn{5}{r}{}
\end{tabular}

Untuk mengetahui lebih jelas dalam membandingkan skor rata-rata pretest, posttest, dan $\mathrm{N}$-gain pada keterampilan berpikir kritis siswa per-indikator dapat dilihat pada Tabel 1.5 .

Tabel 1.5 Capaian Keterampilan Berpikir Kritis pada Tiap Indikator

\begin{tabular}{|c|c|c|c|c|c|c|}
\hline \multirow[t]{2}{*}{ No } & \multirow[t]{2}{*}{ Indikator } & \multirow{2}{*}{$\begin{array}{l}\text { Nomor } \\
\text { soal }\end{array}$} & \multicolumn{2}{|c|}{ Skor } & \multirow{2}{*}{$\begin{array}{c}\% \\
\text { N-Gain }\end{array}$} & \multirow[t]{2}{*}{ Kriteria } \\
\hline & & & Pretest & Postest & & \\
\hline 1 & $\begin{array}{l}\text { Memberikan } \\
\text { Penjelasan } \\
\text { Sederhana }\end{array}$ & $1,2,10$ & 141 & 273 & 51,76 & Sedang \\
\hline 2 & $\begin{array}{l}\text { Membuat } \\
\text { Inferensi }\end{array}$ & 3,9 & 103 & 157 & 33,54 & Sedang \\
\hline 3 & $\begin{array}{l}\text { Memberikan } \\
\text { Penjelasan Lebih } \\
\text { Lanjut }\end{array}$ & 7,8 & 121 & 199 & 54,55 & Sedang \\
\hline 4 & $\begin{array}{l}\text { Mengatur Strategi } \\
\text { dan Taktik }\end{array}$ & $4,5,6$ & 188 & 307 & 57,21 & Sedang \\
\hline \multicolumn{5}{|c|}{$\begin{array}{ll} & \text { Rata-rata }\end{array}$} & 49,27 & Sedang \\
\hline
\end{tabular}

Berdasarkan data pada tabel di atas indikator KBK yaitu pertama memberikan penjelasan sederhana memilikir skor pretest 141 dan skor posttest 273 dengan \%N-Gain 51,76\% memiliki kategori sedang. Indikator kedua, membuat inferensi memiliki skor pretest 103 dan skor posttest 157 dengan $\% \mathrm{~N}$ Gain 33,54\% memiliki kategori sedang. Indikator ketiga, memberikan penjelasan lebih lanjut memiliki skor pretest 121 dan skor posttest 199 dengan \%N-Gain $54,55 \%$ memiliki kategori sedang. Indikator keempat, mengatur strategi dan taktik memiliki skor pretest 188 dan skor posttest 307 dengan \% N-Gain 57,21\% memiliki kategori sedang. Berdasarkan hasil pengolahan data secara keseluruhan 
dari empat indikator keterampilan berpikir kritis (KBK) yang diujikan memperoleh rerata $\% \mathrm{~N}$-Gain 49,27\% sehingga termasuk kategori sedang.

Data hasil analisis soal uraian untuk mengukur peningkatan keterampilan berpikir kritis (KBK) siswa yang telah dipaparkan sebelumnya dari keempat indikator yang diujikan memiliki peningkatan dalam kategori sedang. Untuk lebih jelas dapat kita lihat dari Gambar 1.3.

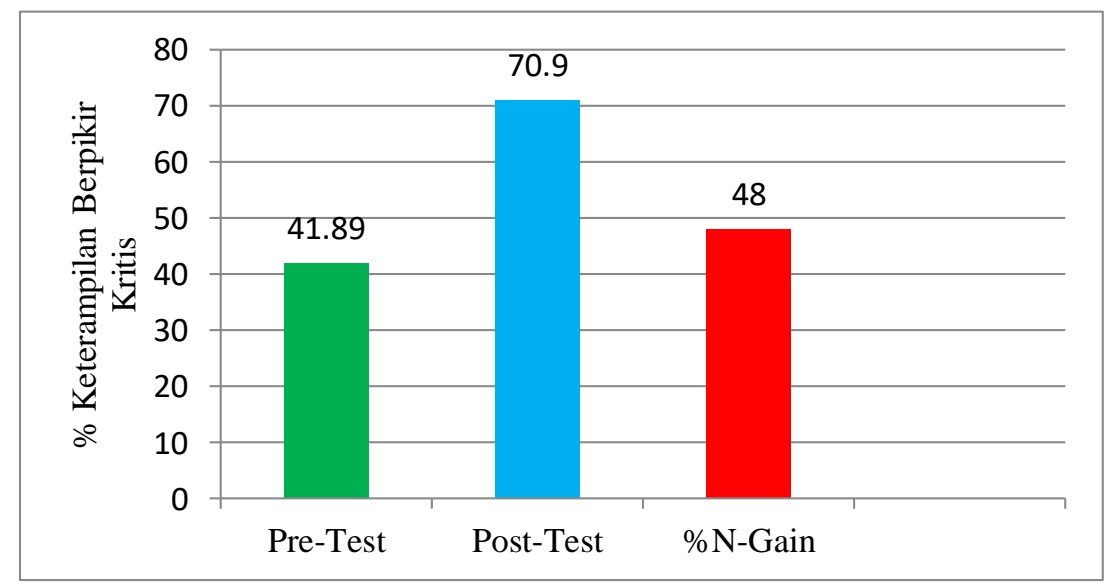

Gambar 4.2 Peningkatan Keterampilan Berpikir Kritis Siswa

Berdasarkan data hasil analisis soal uraian pretest dan posttest dari 33 siswa terdapat 4 siswa yang memiliki peningkatan KBK dalam kategori tinggi dengan nilai \% N-gain > 70, 25 siswa yang memiliki peningkatan KBK dalam kategori sedang dengan nilai \% N-gain 30-70, 4 siswa yang memiliki peningkatan KBK dalam kategori rendah dengan nilai $<30$.

Nilai rata-rata yang diperoleh siswa untuk pretest 42 , posttest 71 , dan $\% \mathrm{~N}-$ gain 48. Nilai N-gain menunjukkan efektifitas pembelajaran dengan kategori sedang. Hasil tersebut menunjukkan bahwa terdapat peningkatan keterampilan berpikir kritis siswa dengan menggunakan IPBM dalam pembelajaran dari pretest ke posttest. Peningkatan keterampilan berpikir kritis sejalan dengan hasil penelitian yang dilakukan Wan Syafii dan Ruhizan Mohd Yasin (2013) menyatakan bahwa penggunaan modul soal berbasis masalah dapat meningkatkan keterampilan berpikir siswa yaitu salah satunya keterampilan menyelesaikan masalah di mana siswa mencoba sendiri untuk memecahkan masalah yang diajukan dengan menggunakan konsep-konsep yang telah mereka pelajari dan untuk menghubungkan pengetahuan mereka untuk memecahkan masalah.

Selain itu penelitian serupa yang dilakukan Rubini (2013) membuktikan bahwa model pembelajaran yang menempatkan siswa dalam persamaan dengan berbagai pendekatan seperti pendekatan kontekstual, teknologi sains dan masyarakat, penyelidikan bebas, dan dengan menggunakan metode interaktif melalui diskusi kritis dan analitis, kolaboratif, induktif, Deduktif, dan reflektif, dapat meningkatkan kemampuan berpikir kritis (Dougherty, 1997; Gokhale, 1995; Zohar, 1994; Splitter, 1992). Kemampuan berpikir kritis sangat penting terutama 
untuk memahami pengertian tertentu, dengan keahlian dasar menggunakan relasi (pola sebagian dan keseluruhan, analisis dan sintesis, urutan dan urutan, deduksi logis), transformasi (analogi, metafora, induksi logis) dan sebab akibat (prediksi, kesimpulan, penilaian, evaluasi).

\section{KESIMPULAN}

Kesimpulan yang dapat diambil dari penelitian yang dilakukan adalah sebagai berikut: 1) Telah berhasil dikembangkan produk berupa modul pembelajaran interaktif yang berbasis masalah yaitu Interactive Problem Based Module (IPBM) untuk siswa kelas VII SMP yang berisi materi tentang Kepadatan Populasi dan Pencemaran Lingkungan. IPBM yang telah dikembangkan memiliki beberapa karakteristik yaitu aspek pedagogi, aspek konten, aspek teknis dan aspek estetika yang sesuai dengan karakter siswa. Aspek teknis memiliki karakteristik sebagai berikut : a) Self instuctional yaitu modul dapat digunakan secara mandiri dan tidak tergantung pada pihak lain, b) Adaptive yaitu penggunaan modul dapat disesuaikan dengan perubahan atau perkembangan ilmu pengetahuan dan teknologi serta fleksibel dalam penggunaannya, c) User friendly yaitu modul mudah digunakan oleh pemakainya, baik dalam merespon maupun mengakses sesuai keinginan. IPBM yang dihasilkan dalam proses penelitian menunjukkan bahwa IPBM memiliki penilaian dalam kategori sangat baik. Penggunaan IPBM dalam pembelajaran dapat meningkatkan Keterampilan Berpikir Kritis dan Penguasan Konsep siswa dalam belajar IPA.

\section{Referensi}

Arsyad, A. 2013. Media Pembelajaran. Jakarta: Rajawali Pers

Costa, A.L. 1988. Developing Mind. Association for Supervision and Curriculum Development : USA

Dahar, R.W. 2011. Teori-teori Belajar. Jakarta: Gramedia

Fraenkel, J.R \& Wallen, N.E. 2011. How to Design and Evaluate Research in Education. New York: McGraw-Hill High Education.

Hake, R. R. 1999. Analyzing Change/Gain Scores. http://www.physics.indiana. edu/ sdi/AnalyzingChange-Gain.pdf. Diakses tanggal 23 januari 2016

Purwanto, D \& Yuliani. 2013. Pengembangan media komik IPA terpadu tema pencemaran air sebagai media pembelajaran untuk siswa SMP kelas VII. Jurnal Pendidikan Sains e-Pensa, 01(01), 71-76.

Rubini, B \& Sofyan, D. 2013. Building Learning Community to Enchance Staff's Capability in Basic Science Learning for non-Science Student. International Journal of Scientific \& Engineering Research, 4(12), 128133.

Sada, M.A \& Yusri. 2016. Prospects of Problem-Based Learning in Building Critical Thinking Skills among Technical College Students in Nigeria. Mediterranean Journal of Social Sciences, 7(3) 
Sudijono,A. 2005. Pengantar Evaluasi Pendidikan. Jakarta: PT. Raja Grafindo Persada.

Suprijono, A. 2010. Cooperative Learning. Yogyakarta: Pustaka Pelajar.

Syafii, W \& Yasin, M.R. 2013. Problem Solving Skills and Learning Achievements Through Problem-Based Module in Teaching and Learning Biology in High School. Asian Social Science,9(12) 